\title{
Investigating EFL Students' Perceptions on E-learning Paradigm-Shift During Covid-19 Pandemic
}

\author{
Mohammad Naim Rahim ${ }^{1}$ and Shanti Sandaran Chandran ${ }^{2}$ \\ ${ }^{1}$ Kunduz University, Kunduz, Afghanistan \\ ${ }^{2}$ Universiti Teknologi Malaysia, Johor Bahru, Malaysia \\ mnaim.rahim@gmail.com
}

\begin{abstract}
ARTICLE HISTORY
Received : 18 January 2021

Revised : 28 January 2021

Accepted : 14 March 2021
\end{abstract}

\section{KEYWORDS \\ EFL Students \\ Covid-19 Pandemic \\ Perceptions \\ E-learning \\ Paradigm-Shift}

\begin{abstract}
The purpose of this research article is to investigate the perceptions of EFL students during the Covid-19 pandemic on implementing e-learning at university-level education in the EFL context of Afghanistan. The covid-19 pandemic has globally led the universities towards a paradigm-shift. As well as the instant development of ICT has restructured the content and the context of education particularly teaching and learning EFL. To determine the barriers and opportunities of implementing e-learning in EFL education, a qualitative method with semi-structured interview are applied to perceive the perceptions of EFL students. The study purposefully selected EFL students $(\mathrm{N}=21$ male and female) from Afghanistan universities as respondents. The data from the semi-structured interview is analyzed thematically. Results show that EFL students perceive e-learning approach as a better alternative to traditional face-to-face classrooms. Despite being regarded as an interactive method for EFL education, the lack of regular electricity connection, low internet bandwidth, high costs of ICT tools, lack of infrastructures, and lack of ICT knowledge of the teachers and students are perceived to be the barriers to implementing elearning in Afghanistan higher education. In brief, the study contributes to establishing an in-depth understanding of the e-learning implementation and EFL instructions in Afghanistan higher education during the Covid-19 pandemic.
\end{abstract}

\section{Introduction}

Due to the rapid advancement of technology, a revolution has erupted on all surfaces of educational life, particularly in teaching and learning a foreign language. The twenty-first century is the age of intelligence where academic tasks are designed based on the influence of technology and educational innovations. According to Rahim (2019), teaching and learning a foreign language is now surrounded by many technological trends that have gained the interest of language educators as well as learners. Considering this, the need for today's education requires the teachers and the educational instantiations to restructure the strategies for effective educational practices and upgrade their teaching and learning platforms to meet the global needs. These transformations especially during the Covid-19 pandemic need to be based on the authentic investigations of the e-learning approaches.

However, many scholars have investigated the potential of applying e-learning in education to help students in improving their learning performance. According to Guragain (2016), the instructors can upload and present teaching content, track learners' activities, assess learners' knowledge, and keep students updated about the course. Rahim \& Sandaran (2020), also stated that technological approaches will benefit both teachers and learners. Despite of this, when this paradigm-shift is discussed in the context of Afghanistan, there is a basic understanding of information and communication technology's (ICT) potentials and its retractions. Though like other new terminologies of learning in the age of digitalization, elearning does not have an acceptable definition among educators in Afghanistan, still, there is an intent that how technological innovations enhance English as Foreign Language (EFL) education.

Firstly, e-learning can be an online approach that makes the knowledge or language output available to the students and removes time restrictions or geographic proximity which is commonly called anytime and anywhere education. From this, it can be concluded that e-learning refers to the conveyance of education with the assistance of interactive electronic technology. According to Rahim (2021), the internet, social media, computers, smartphones, tablets, and innovative educational gadgets are recently designed for in-class and out-class effective language practices. It is assumed that they have a lot to offer if educators integrate them into education, particularly in foreign language teaching and learning context. Therefore, the current study investigates the perceptions of EFL students to highlight the potentials and restrictions of applying e-learning in EFL education to motivate institutions to benefit from its contributions. 
Secondly, the term English as a Foreign Language itself is not focused on any particular class or very structured course anymore. Many people learn language through the influence of technological tools and communicate proficiently. Whereas, Vygotsky (1978) theorized that language learning comes from social interactions. Therefore, when all these technological trends come to foreign language teaching and learning, still there are challenges in terms of their alignment and integrations into EFL classrooms. Paradigm-shifting in educational approaches, specialization in the context of languages itself such as ELT, EFL, ESL, and integration of technology into teaching and learning, all motivate this study to investigate more on e-learning and EFL education, particularly in the context of Afghanistan.

In this study, in addition to the review of the previous literature on barriers and opportunities for e-learning implementation in teaching and learning EFL, the main focus is the perceptions of EFL students at university-level education in the EFL context of Afghanistan. A demonstration of the analysis of the findings is extended by recommendations hindering credible and practical results to facilitate the effectiveness of e-learning implementation in EFL education. Based on the best of the investigator's knowledge and available studies, this area of research is unexplored in Afghanistan's context, particularly in higher education institutions. Since e-learning integration is a new educational experience at all public and private universities of Afghanistan.

Accordingly, the study followed the objectives of the ministry of higher education to support the new policies (HELMS) developing for e-learning implementation in the higher education of Afghanistan. Since 2013, MoHE is conducting several phase of training for academic members in all public and private universities all over Afghanistan to achieve their professional goals toward the implementation of e-learning. Similarly, the quality assurance committee is another branch in MoHE intending to develop the quality of teaching and learning at universities. Therefore, the efforts in the current study are aligned with the potentials that the higher education attempted to the use of e-learning and the objectives aiming to continue further practical steps toward the educational advancements.

In addition, reviewing previous studies (Jebreen, 2017; Hussain et al., 2018; Al-Azawei, et al., 2016; O’Doherty et al., 2018; Rajaee, 2015; Rahim \& Sandaran, 2020; Rahim \& Sandaran, 2021; and Lakbala, 2015), this study identified research gaps. Most of the studies that investigated EFL education and e-learning approaches have applied quantitative research methodology and very few used mixed methods or qualitative approaches. Since education, particularly teaching and learning EFL is closely related to social sciences, therefore, the current study attempts to do a qualitative study to obtain an in-depth understanding of the issue as well as to fulfill the research gaps. The research objectives include investigating the perceptions of EFL students towards the current status of e-learning implementation at university-level education in Afghanistan, the barriers and opportunities of implementing it, as well as the available potentials for implementing elearning in this context. To achieve these objectives, the following research questions are addressed:

a. How do EFL students perceive the implementation of elearning at university-level education in the EFL context of Afghanistan?

b. What are the barriers and opportunities of implementing e-learning at university-level education in the EFL context of Afghanistan?

c. What are the potentials for e-learning implantation at university-level education in the EFL context of Afghanistan?

\section{Literature Review}

\subsection{Conceptual Framework}

The background, literature review, theories, and principles led to the formulation of the following conceptual framework in this study to demonstrate the relations and conceptual indications of the topics.

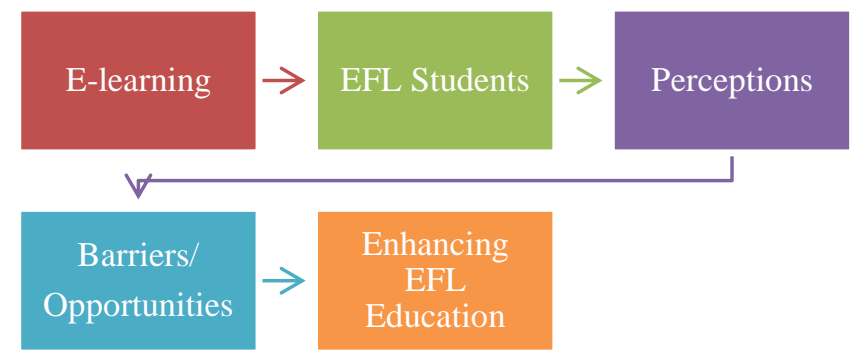

Figure 1. Conceptual Framework of the Study

E-learning is the fundamental concept that the study investigates. Since it is implemented as an approach in teaching and learning EFL, there is a relationship between the EFL students and e-learning. To investigates this relationship, EFL students' perception is considered. Therefore, the study determines the statues of e-learning implementation and focuses on EFL students' perceptions to highlight the barriers and opportunities which enhances the EFL education.

\subsection{Barriers of Implementing E-Learning}

Based on the studies (Jebreen, 2017; Hussain et al., 2018; Al-Azawei et al., 2016; O’Doherty et al., 2018; Rajaee, 2015; Rahim \& Sandaran, 2020; Rahim \& Sandaran, 2021; and Lakbala, 2015), the barriers are commonly related to the students' anxiety within an unfamiliar e-learning platform, new e-learning modules, and the alignment of e-learning within the contexts of teaching and learning. Besides, lack of ICT skills, technical 
supports, and lack of infrastructure is considered to be the major barriers to e-learning implantation.

According to Gutiérrez et al. (2016), the problems that the students face while using e-learning may be psychological, such as anxiety about the use of new methods or problems in communication between coursemates or professors. The study recommended a solution to this barrier that professors have to know the obstacles facing by students and do maximize efforts and investments involved in making high-quality courses to reduce the obstacles within the online communications.

Aligned with the study above, Jebreen (2017) also stated that there is a relationship between the academic years and the transition from traditional education to e-learning. The study resulted in a strong positive correlation between the year that students move from the first years to the top years of their education. Therefore, it is highlighted that transition from traditional approaches to technology-generated methods can be considered as a barrier for EFL education. Based on this study, we can conclude that the more the students' awareness increases towards the use of technology in language practices, the more they are willing to use the e-learning modules.

Besides, a study in the UK by Ali et al. (2018), listed 68 unique barriers which are thematically grouped into four conceptual categories, i.e. Technology (T), Individual (I), Pedagogy (P), and Enabling Conditions (EC). As a solution, it is proposed to give training to new students on the use of technology and e-learning. This indicates the similarity between the barriers in different regions. We can conclude that it's not only because of the traditional approaches but also there are inter-connected factors such as the advancement of technology and its influences on education which can be listed as the barriers for implementing elearning globally.

In sum, the key barriers of implementing e-learning identified by several studies in different contexts of education are students' anxiety within the unfamiliar elearning platforms, inadequate awareness of e-learning approaches by learners, lack of e-learning literacy of both teachers and students, and un-alignment of the contents and e-learning approaches. According to Lakbala (2015), to overcome these barriers, e-learning training has to be provided for teachers and administrators as well as financial and technical support should be considered.

\subsection{Opportunities for Implementing E-Learning}

Reviewing the literature, the study highlighted some of the major opportunities for implementing e-learning which has the main influence on teaching and learning EFL. For instance, language learners can have a variety of integrated tasks and flexible foreign language learning approaches in line with their inclinations and needs.
According to Kisanga \& Ireson (2015), successful elearning implementation is a means to solve the authentic concerns of teaching and learning. This affirmation supports the idea that empowering e-learning implementations particularly in EFL education in Afghanistan is also a means. In line with the studies in different countries on e-learning, the current study also highlighted research that has been done in Afghanistan. Shahnaz et al. (2014) developed an e-learning model called LIVES (Learning through Interactive Voice Educational System). These efforts are the evidence that verifies the attempts in Afghanistan for e-learning implementation and motivates the researchers to extend the studies.

However, like many other Asian countries, e-learning has become a fundamental issue for Afghanistan's higher education since e-learning has a major influence on teaching and learning EFL (Rahim \& Sandaran, 2020). Today, not only personal-life but even educational-life is affected by ICT trends. Education particularly teaching and learning EFL is a core fragment in these technological revolutions. Therefore, relying on the available literature, the current study is encouraged to indicate efforts on exploring barriers and opportunities for e-learning implementation.

Prior studies investigated that there is a positive attitude toward e-learning implementation by academic members, undergraduate students, and organizational staff. According to Hussain et al. (2018), tracking student engagement in different educational learning activities, e-learning encourages high-quality learning and comprehensive analysis of student engagement can help to minimize course dropout rates. Technology most particularly e-learning provides this opportunity for foreign language learners to have a flexible learning platform.

In the context of Afghanistan, traditional approaches for teaching and learning EFL led EFL education to teacherdominated classrooms (Rahim \& Sandaran, 2020), whereas technology attempts to transform this atmosphere into a more dynamic context. According to Rajaee (2015), learners' requirements changed since they are involved in these new technological innovations. Besides this, paradigm-shifting in language teaching methodology is an issue for teachers. As Domingo \& Garganté (2016) stated that pedagogy is transformed from a teacher-centered to a student-centered approach.

Finally, when personalized learning is discussed, students can decide what to learn and how to learn. Also, elearning as an educational approach currently provides the opportunity for both EFL teachers and the learners to decide on the most appropriate contexts and the accurate contents to teach and learn. Gillett-Swan (2017) stated that educational policy developers are becoming increasingly aware of the diversity of their current potential. According to Rahim \& Sandaran (2020), e-learning functions as an effective approach for foreign language 
learning which integrates cooperation, collaboration, creativity, and critical thinking skills. Whereas, twentyfirst-century education particularly EFL is more on promoting cooperation, collaboration, creativity, and critical thinking. This is not effectively possible without the enhancement of e-learning as an approach to pave the way for effective learning.

\subsection{Teaching and Learning EFL in Afghanistan}

For decades, EFL is a core skill not only for Afghanistan higher education but also as a global requirement for employment or communicative competencies. However, EFL is a subject taught in Afghanistan's schools and universities as a compulsory subject. According to Rahim \& Sandaran (2021), the importance of the English language in Afghanistan indicated a need that it is taught as a subject from fourth grade until high school. Besides, English as a foreign language is a compulsory university subject that is offered for another two years at the undergraduate level in every field of studies in Afghanistan universities. Therefore, EFL is one of the major priorities besides ICT skills for MoE and MoHE in Afghanistan.

According to Rahim \& Sandaran (2021), the educational curriculum of ministry of education was revised during the 2003s. The upgraded curriculum concentrates more on new teaching and learning trends. It is more student-centered in the content of EFL education. Thus, these indications motivate further investigation on the integration of the language teaching approaches and highlighting the major needs for the implementation of e-learning in EFL education.

In terms of higher education, the national educational curriculum is revised during 2012s. The new curriculum is focusing on enabling the students to be competent in the English language. The core objectives are to help the learners to have enough communicative competence as well as be proficient in the school subjects and enhancing their communicative proficiency. These efforts are also aligned with the private sector in the country. According to Noori et al. (2017), EFL has developed as a dynamic skill in both academic and non-academic platforms.

To conclude, a paradigm-shifting happened toward learning and teaching EFL in Afghanistan. Based on (MoHE, 2011), EFL is being the medium of instruction in most institutions and universities, particularly in medical science. Also, the MoHE commits to transform the language of instruction from Persian to English for the majority of the fields. Since it is believed that it will open the areas for research and international academic communications. Therefore, this paradigm shift in higher education requires the institutions to transform their traditional approaches of EFL teaching and learning to technology-integrated instructions.

\section{Method}

The study applied a qualitative approach with a semistructured interview. As Creswell (2017) stated that the purpose of the qualitative approach is to understand, from within, the subjective reality of the research participants. This will not be accomplished with superficial knowledge about a large, representative sample of individuals. Rather this research aims to reach people within the study area who can share their unique slice of reality so that all slices together will demonstrate the range of variation within the study context. Hence, the qualitative approach and the semi-structured interview are suitable for the current study.

A semi-structured qualitative study offers topics and questions to the interviewee, but they are carefully designed to elicit the interviewee's ideas and opinions on the topic of interest, as opposed to leading the interviewee toward preconceived choices. They rely on the interviewer following up with probes to get in-depth information on topics of interest. Similarly, Blandford (2013) stated that a semi-structured qualitative study involves systematic, iterative coding of verbal data, often supplemented by data in other modalities. Therefore, it suits the best for the current research.

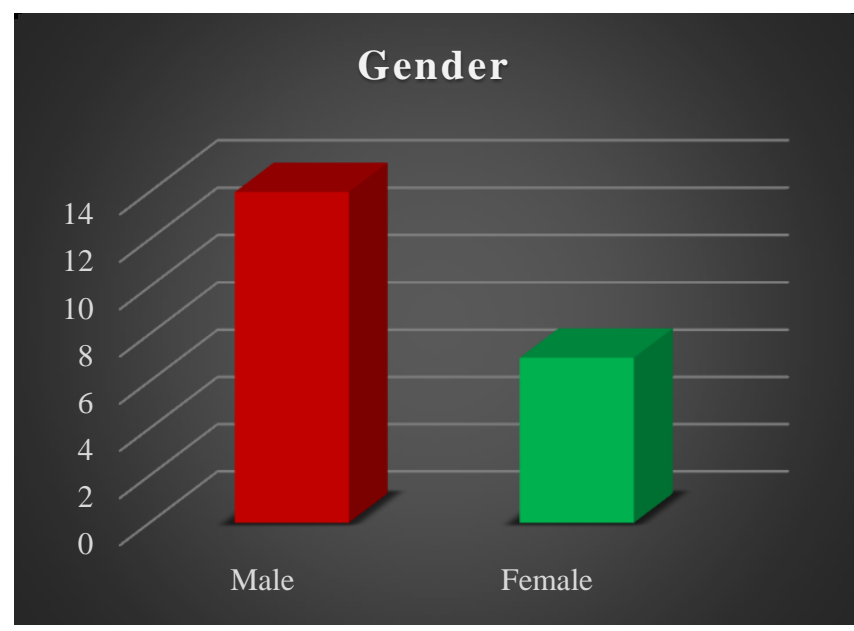

Figure 3. Gender of Respondents

The respondents of the study are EFL students of particular universities in Afghanistan. According to Blandford (2013), recruiting respondents for a study, it is important to consider their motivations for participation. Therefore, the researchers selected the respondents of the study from the discipline practitioners purposefully because this technique led to spending more time and extracting accurate information. The respondents include a total of 21 male and female EFL students of public and private universities of Afghanistan who voluntarily participated in this study. The small sample size, according to Elmusharaf (2012), adds credibility to the sample when a potential purposeful sample is larger than one can handle. Within the current study, one of the researchers himself is an academic 
member in one of the universities in Afghanistan, therefore, the researcher used direct contact to recruit the samples.

The study used a semi-structured interview which is adapted based on the objectives and the main research questions of the study as the data collection tool. Interviews are best suited for understanding people's perceptions and experiences. As Flick (2009) stated that practices are only accessible through observation, interviews and narratives merely make the accounts of practices accessible. Therefore, a semi-structured interview can uncover rich descriptive data on the personal experiences of participants.

Also, the semi-structured interview can provide an indepth description as well as detailed perceptions generated by the respondents of the study, as it seeks to investigate and recognize the personal performances, experiences, and perceptions of the participants. As stated earlier, a semistructured interview uses open-ended questions to get lengthy and descriptive answers rather than close-ended questions. Accordingly, Newton (2010) stated that a semistructured interview compromises the opportunity to make the data-rich. Therefore, this best suits the objectives of the study and leads to systematic data collection.

The data is transcribed from the interviews to easily identify the themes and get an understanding of the data gathered. Therefore, the method for data analysis is thematic. According to Braun \& Clarke (2013), thematic analysis is the process of identifying patterns or themes within qualitative data. In addition, data from the different respondents will validate through a triangulation process (Miles \& Huberman, 1994). The themes were based on the research questions which were thematically-divided into sub-themes to give the ball to the interviewees to get an indepth understanding of the issue. As Arthur \& Nazroo (2003), emphasize the need for appropriate interview development, introduction, opening questions, core indepth questions, and closure. The researchers also identified sub-themes from the main research questions of the study to prepare the verbatim of the semi-structured interview.

Since the data analysis in qualitative research involves identifying, coding and categorizing patterns or themes found in the collected data (Vaismoradi et al. 2016), therefore, the researchers encoded the transcribed data from the interviews to find out the patterns. Then, the encoded data is grouped into sub-themes, which is later categorized into themes that were found in the data. Based on the data analyzed, the thematic investigation is provided to address the gaps.

Identifying the patterns in a semi-structured interview involves some sort of coding the data. Blandford (2013), clarifies the process as creating useful descriptors of the units, such as single words, phrases, extended utterances, objects featuring in photographs, actions noted in videos, etc., and then comparing and contrasting coded units to construct an analytical narrative based on the data. For the current study, thematic analysis is applied as Braun \& Clarke (2006) also stated that thematizing is a generic skill across the qualitative approaches and the thematic analysis builds directly on this skill.

\section{Results \& Discussion}

Based on the objectives of the study, the researchers transcribed the data, coded the patterns, and recognized the co-related themes of the findings from the semi-structured interview to investigate the perceptions of undergraduate students' thematically into the main themes in this section which are E-learning Awareness Among EFL Students in Afghanistan, EFL Education Would Be Different by Implementing E-Learning, E-learning as an Ideal Approach for EFL Learners, Lack of Infrastructures and Technical Supports, and Potentials to Contribute E-Learning Implementations. Therefore, the findings of the study in this section are thematically discussed and presented through the analysis of the following.

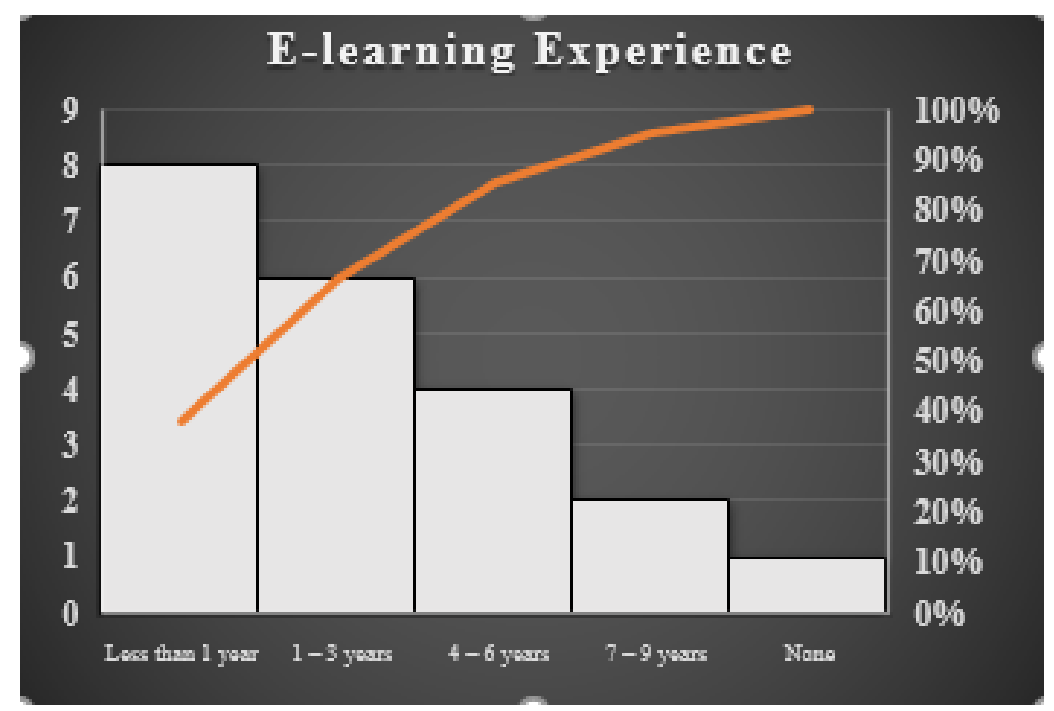

Figure 4. E-learning Experience of Respondents 


\subsection{E-learning Awareness Among EFL Students in Afghanistan}

Based on the EFL students' perceptions, the study highlighted that there are basic understandings of the elearning approaches among the students. As undergraduate students stated that "E-learning is utilized for electronic technology that helps us to access educational purposes easily through using the computer, internet, media, and other technological devices". They also added that "By applying e-learning, we access to good resources, finding information, creating communication with each other, learning about how these devices work and become aware of other cultures and language aspects".

This finding of the study is aligned with a study done in a different context by Yacob et al. (2012), who studied student awareness concerning e-learning, and the results presented that males and females students both have the awareness of e-learning. Based on the objectives of the currents study, students' awareness of the use of e-learning will best motivate the e-learning implementation at university-level education in the EFL context of Afghanistan.

Besides, the findings of the study also highlighted that undergraduate students benefited from the potential contributions of e-learning in their language learning circumstances. As an EFL student stated, "E-learning means to use technology for educational purposes. It involves the use of digital tools for teaching and learning". The EFL students also added, "E-learning makes use of technological tools to enable learners to study anytime and anywhere. It also involves the training, delivery of knowledge and motivates students to interact with each other, as well as exchange and respect".

Similarly, the findings of a study by Alkharang \& Ghinea (2013) also stated that e-learning has emerged as a necessity to meet the challenges posed by the development of information technology and its potential for greater access to knowledge. This illustrates the potentials of using e-learning and its contributions to university-level education in the EFL context of Afghanistan.

On the other hand, the findings of the study highlighted that the EFL students already registered for e-learning courses beyond the university classes and get benefit from its potential. As an EFL undergraduate student stated, "I registered a single course through e-learning. The course was about (How to be a Fluent Speaker). It was an online course for about three months". The EFL student also added that "After successfully finishing the course, they gave a certificate. The main purpose of this course is to enable the learners to communicate fluently in the target language".

The findings highlighted that there are enough potentials and awareness of using e-learning among undergraduate students which motivates the potentials for the implementation of e-learning at university-level education in the EFL context of Afghanistan. A similar study intended that there is no resistance to change by learners while they are involved in these new technological innovations (Rajaee, 2015). However, successful e-learning implementation depends on the self-motivation of individuals to study effectively.

In short, the findings illustrate the students' awareness of the use of e-learning in EFL education. It also indicates the influence and effectiveness of e-learning in EFL education that the students' attempted to benefit it. Considering the level of the students', e-learning content is also an issue for e-learning developers. As the findings of a similar study by Allen \& Seaman (2014) also stated that policymakers and e-learning developers should distinguish the characteristics of the learners, recognize developmental tasks in line with the learners' age while learners are one of the most important factors in education.

\subsection{EFL Education Would Be Different by Implementing E-Learning}

Initially, the findings of the study highlighted that EFL students at universities have already performed well in elearning platforms available online. As one of the EFL students stated, "I have registered only one course through e-learning. That was Improve Your Vocabulary Fast". The EFL student also added, "It was a website and they send me a list of words every day. The words were easy and everyday words that we need to know in daily conversation". Hence, students' e-learning experience is evaluated very well. As the student stated, "It was very useful. I learned a lot of new words and I improved my speaking ability as well".

EFL students also stated that going to courses costs too much, but with e-learning, we can learn different things with little cost. It reduces learners' anxiety and stress during a conversation. As one of the EFL students stated, "Somehow, I am very comfortable with $e$ learning". Despite the findings of a previous study done by Gutiérrez et al. (2016) which indicated the problem that the students face while using e-learning may be psychological, such as anxiety about the use of new methods or problems in communication between course-mates or professors, the current study highlights that students are more comfortable while using e-learning.

The findings also confirmed that EFL students evaluate e-learning well. As an EFL student stated, "My elearning experience is very good and useful to me because I learn a lot of things in the English language when I learned English online". Similarly, the student added, "I know a lot about structures, tenses and how we can speak English so they are my e-learning experience". In this regard, the finding of a study by Hussain et al (2018) also stated that student engagement in e-learning encourages high-quality learning. 
Furthermore, it is exposed that EFL education would be different by implementing e-learning because of its potentials to provide practices for all four skills of language learning. EFL students also explained their e-learning interactions with teachers quite positively. As an EFL student stated, "E-learning support interaction and this interaction with our teacher include; personal response system when facing a problem, our teacher gives us to answer directly and always try to have assessed learning and all the time consults their students individually". The student also added, "All interactions among teacher and learners have instructional purposes and focus on meaningful learning".

This indicates that implementing e-learning, EFL education would be more effective. Students would learn the language faster and they would be able to communicate in any situation. The level of the knowledge of students would be high if they learn through e-learning. Since elearning provides authentic tasks based on situated contexts. Kisanga \& Ireson (2015) also demonstrated that successful e-learning implementation is a means to solve the authentic concerns of teaching and learning.

In brief, the findings of the current study reveal that students' engagement in teaching and learning is quite high through the use of e-learning. As an EFL student stated about the interactions with the teachers through elearning, "In our Educational Technology Class, our teacher uses a projector for presenting the lesson. I like the lesson very much because I learned all the parts of the lesson. The teacher is very comfortable with the lesson as well". The students also added, "By using e-leaning tools in the class, the teacher explains every section explicitly and completely. In our class, there is a good connection between students and teachers through the use of $e$ learning”. This indicates how EFL classrooms enhanced using e-learning approaches.

\subsection{E-learning as an Ideal Approach for EFL Learners}

The findings of the study also demonstrated that EFL students consider the e-learning approach as an ideal method for their language learning. However, there are no single methods of teaching and learning in language pedagogy and the existence of various methods make language education different from other fields (Rahim \& Sandaran, 2020). As an EFL student stated, "As we know, EFL education involves many methods and techniques". The student also added, "That is the reason that EFL education would be different by implementing $e$ learning”. Similarly, the findings of a study by Solangi, et al. (2018) also stated that e-learning is the ideal form of delivery for higher education students.

Initially, the findings of the study clarify that EFL learners practice the language interactively while using elearning platforms. E-learning engages the student in learning a foreign language authentically, however, it depends on students' and teachers' motivation. As an EFL student stated, "In e-learning, students come online for learning and there may not be such courses to get without using devices and it is somehow good especially to expand our knowledge also another benefit in e-learning is the accessibility of them anywhere and anytime". The student also added, "E-learning avoid time-consuming and reduces the costs also at the same time we achieve our needs". Similarly, the findings of the study Rahim (2021) also evaluated that e-learning provides anytime and anywhere education and increases the student's interaction, motivation, and engagement.

The EFL students also reflected that e-learning provides visual language learning tasks which enhance language proficiency. As an EFL student stated, "Through elearning, I see charts, videos, or listen to different audios and use the computer for searching materials". This indicates how EFL students are engaged in the e-learning platform. Also, these variations in terms of visualizations and attractiveness as well as accessibility make e-learning students' ideal form of language learning. As an EFL student stated, "I would have more access to educational materials through e-learning. For this reason, I learn very quickly and easily through e-learning".

These are aligned with the studies that have been done by Kisanga \& Ireson (2015), Hussain et al. (2018), Domingo \& Garganté (2016), Gillett-Swan (2017), Rahim \& Sandaran (2020), Rahim (2021), Solangi et al. (2018) and Ahmad et al. (2020) that using e-learning, language learners can have a variety of integrated tasks and flexible foreign language learning approaches. E-learning approaches facilitate foreign language learners with a set of interactive tasks through which the learners are involved in every stage of learning. Therefore, EFL learners consider it as an ideal approach for their language practices.

\subsection{Lack of Infrastructure and Technical Support}

In general, EFL students perceived that before the barriers of e-learning implementation, there is a wide range of opportunities extending the implementations of elearning, particularly at university-level education in the EFL context of Afghanistan. The findings illustrate that while using e-learning, EFL students faced some unanticipated events which make students frustrated. Based on the findings, these barriers are technical challenges, most of the time, poor internet connection, and lack of infrastructure. Whereas, in terms of the opportunities, the findings illustrate that there are more chances for completing the e-learning course successfully.

In terms of lack of infrastructure and technical supports, an EFL student stated that "E-learning needs tools, in our country, most people do not have access to the internet and ICT tools". The findings also demonstrate that most of the EFL students face challenges of using e-learning due to the poor internet connection and lack of ICT tools. As an EFL student stated, "I had registered a course for improving my 
vocabulary but most of the time I was not able to download the content due to poor internet connection". This indicates how the lack of infrastructure and technical support affects the use of e-learning in EFL education.

The findings of the study identified that there is no specific pedagogical challenge against the e-learning implementation by EFL students for teaching and learning EFL at universities, but there is a lack of infrastructure and technical challenges that may affect to unsuccessful implementation of e-learning. Besides, lack of technical support to integrate the traditional content with technology is also a barrier to implement e-learning. Aligned with the finding in the current study, there is a similar study determined lack of infrastructure as the most highlighted barriers of e-learning implementation (Shirkhani et al., 2016).

EFL students also stated that "Failures of electricity, lack of computers and technical problems are the barriers happen in e-learning". There are still potentials to implement e-learning approaches as an EFL student stated, "There are many chances for completing an $e$ learning course successfully. However, it depends on the learners if they want to use or no". Similarly, the findings of a study by Jebreen (2017) and Junaidi et al. (2020) also showed that there is a relationship between the academic years and the transition from traditional education to elearning. Overall, lack of infrastructure and technical support are considered barriers to implementing e-learning based on the students' perceptions in this study.

In brief, learners stated that most of the barriers while using e-learning relate to technical issues. As one of the EFL students stated, "the first time that I registered for an e-learning course, I was stressed then I get used to it. Being irresponsible and being busy at the time of course. Weak and not suitable internet is another factor and barriers of $e$ learning". Therefore, the findings demonstrate that lack of infrastructure is an issue. As an EFL student also stated, "I as an EFL learner does not have e-learning devices, but some of our teachers bring their own electronic devices like computer and through them conduct us to the e-learning programs for having meaningful learning". It indicates that in terms of technical supports, students also lack the elearning tools.

\subsection{Potentials to Contribute E-Learning Implementations}

Based on the EFL students' perceptions, the investigations indicate that there are still limited opportunities for implementing e-learning at universitylevel education in the EFL context of Afghanistan. Elearning needs the tools and also students' awareness of elearning. As one of the EFL students stated, "The only opportunity that I can mention is the internet. Last year, all classes were equipped with the internet and now students can use it". This identifies that there are steps for improving e-learning implementation at universities.
However, students' awareness of e-learning technology should also be considered.

Besides, EFL students also perceived that the classrooms are equipped with the internet but the internet is slow. It is also stated that e-learning needs high-speed internet and facilitated classrooms. However, e-learning literacy is a factor for both teachers and students. Similarly, a study done by Kisanga \& Ireson (2015), suggested a pretraining of the students and teachers on e-learning skills and educational innovations. However, as one of the primary findings of the study, most of the EFL students stated that they are techno-literate. Many of them can use technology for educational purposes by themselves.

Therefore, the barriers to implementing e-learning for teaching and learning EFL at universities are considered as technical issues and lack of infrastructures while there are optimisms that indicate e-learning implementation at universities is still an opportunity for EFL education. As elearning potentials provide the freedom for language learners to decide on their learning content. In e-learning classes, learning is not limited. The findings also declare that by using e-learning, students feel free of stress and anxiety. All these contributions are considered as the practical contributions to implement e-learning in EFL education.

Finally, EFL students perceived that that e-learning benefits their learning circumstances. Unlike the traditional classroom, e-learning can provide access to the content an unlimited number of times. It also enables learners to access updated content anytime and anywhere (Putri, 2019; Putri et al., 2020). Also, e-learning is a way to provide quick delivery of the lesson and also reduces costs. Optimistically, EFL students registered for e-learning courses. The findings also highlight that EFL students have already performed well in e-learning platforms available online and they are more comfortable while using elearning platforms.

\section{Conclusion}

The study aimed to investigate the perceptions of EFL students towards the current status of e-learning implementation at university-level education in the EFL context of Afghanistan. Therefore, a semi-structured qualitative study is applied to investigate the perceptions of EFL students. the study included a total of $(n=21$ male and female) respondents from particular universities of Afghanistan. The data from the semi-structured interview are thematically analyzed, discussed, and presented. The findings based on the respondents' perceptions indicate that the integration of technology in education is springing up. It motivates both teachers and the students to practice the language authentically and visualizes the learning tasks. According to the results, EFL students are using e-learning objectives. The study examines that e-learning is considered as an applicable approach in EFL education that enhances reliable language practices, motivates the learners 
and teachers, provides the opportunity of anywhere and anytime education, and reduces the students' anxiety and costs.

Lack of infrastructures such as computer labs, e-learning classrooms, and unavailability of the ICT tools as well as technical supports such as poor internet connections, failures of electricity, high costs of ICT tools and internet, and curriculum alignment with technology is also considered as the major barriers of e-learning implementation. The results indicate that there are also potentials by the EFL students that benefiting the contributions of the use of e-learning within the language learning platforms.

\section{Acknowledgement}

For this research paper, the researchers express their sincere appreciation to their colleagues and undergraduate students at Kunduz University as well as fellow friends at UTM Malaysia for their guidance, advice, and motivation.

\section{References}

Afghanistan, Ministry of Education. (2011). Afghanistan Education Curriculum. Kabul: Ministry of Education.

Afghanistan, Ministry of Higher Education. (2015). OBE, SCL, and E-learning Workshop. Kabul: Ministry of Higher Education.

Ahmad, T. S. A. S., Ramlan, Z. S., \& Krishnan, S. K. (2020). Acceptance of Google Classroom for Learning English Exit Test. International Journal of Modern Languages And Applied Linguistics, 4(1), 67-76.

Al-Azawei, A., Parslow, P., \& Lundqvist, K. (2016). Barriers and Opportunities of E-learning Implementation in Iraq: A Case of Public Universities. The International Review of Research in Open and Distributed Learning, 17(5). https://doi:10.19173/irrodl.v17i5.2501.

Ali, S., Uppal, M. A., \& Gulliver, S. R. (2018). A Conceptual Framework Highlighting E-learning Implementation Barriers. Information Technology \& People, 31(1), 156-180. https://doi:10.1108/itp-102016-0246.

Allen, I. \& Seaman, J. (2014) Grade Change: Tracking Online Learning in the United States. Wellesley MA: Babson College/Sloan Foundation.

Blandford, Ann. (2013). Semi-Structured Qualitative Studies. In: Soegaard, Mads and Dam, Rikke Friis (eds.). "The Encyclopedia of Human-Computer Interaction, 2nd Ed.". Aarhus, Denmark: The Interaction Design Foundation.
Braun, V., \& Clarke, V. (2006). Using Thematic Analysis in Psychology. Qualitative Research in Psychology, 3(2), 77---101.

Broadbent, J., \& Poon, W. (2015). Self-Regulated Learning Strategies and Academic Achievement in Online Higher Education Learning Environments: A Systematic Review. The Internet and Higher Education, 27, 1-13. https://doi: 10.1016/j.iheduc.2015.04.007.

Clarke, V. \& Braun, V. (2013). Teaching Thematic Analysis: Overcoming Challenges and Developing Strategies for Effective Learning. The Psychologist, 26(2), 120-123.

Creswell, J. W., \& Poth, C. N. (2017). Qualitative Inquiry and Research Design: Choosing Among Five Approaches. Sage publications.

Domingo, M. G., \& Garganté, A. B. (2016). Exploring the Use of Educational Technology in Primary Education: Teachers' Perception of Mobile Technology Learning Impacts and Applications' Use in the Classroom. Computers in Human Behaviour, 56, 21-28. https://doi: 10.1016/j.chb.2015.11.023.

Elmusharaf K. (2012). Qualitative Sampling Techniques. Training Course in Sexual and Reproductive Health Research; 2012 Jul 31; Geneva. Flick, U. (2009) An Introduction to Qualitative Research. Sage.

Gillett-Swan, J. (2017). The Challenges of Online Learning: Supporting and Engaging the Isolated Learner. Journal of Learning Design, 10(1), 20. doi:10.5204/jld. v9i3.293.

Guragain, N. (2016). E-Learning Benefits and Applications. Helsinki Metropolia University of Applied Sciences.

Gutiérrez-Santiuste E., Gallego-Arrufat, M.J. \& Simone, A. (2016), Barriers in Computer-Mediated Communication: Typology and Evolution Over Time. Journal of e-Learning and Knowledge Society, 12, (1), 107-119.

Harandi, S. R. (2015). Effects of E-Learning on Students' Motivation. Procedia - Social and Behavioral Sciences, $\quad 181, \quad 423-430 . \quad$ https://doi: 10.1016/j.sbspro.2015.04.905.

Hussain, M., Zhu, W., Zhang, W., \& Abidi, S. M. (2018). Student Engagement Predictions in an E-learning System and Their Impact on Student Course Assessment Scores. Computational Intelligence and Neuroscience, $1-21$. https://doi:10.1155/2018/6347186.

Jebreen, I. (2017). E-Learning System - Challenges \& Barriers: A Case Study. International Journal of Computing Academic Research (IJCAR), 6(2), 5966. 
Junaidi, J., Hamuddin, B., Simangunsong, W., Rahman, F., \& Derin, T. (2020). ICT usage in teaching English in Pekanbaru: Exploring junior high school teachers' problems. International Journal of Advanced Science and Technology, 29(3), 5052-5063

Kisanga, D., \& Ireson, G. (2015). Barriers and Strategies on Adoption of E-learning in Tanzanian Higher Learning Institutions: Lessons for Adopters. International Journal of Education and Development using Information and Communication Technology, 11(2), 126.

Lakbala, P. (2015). Barriers in Implementing E-learning in Hormozgan University of Medical Sciences. Global Journal of Health Science, 8(7), 83. https://doi:10.5539/gjhs. v8n7p83.

Miles, M. B., \& Huberman, A. M. (1994) Qualitative Data Analysis an Expanded Sourcebook. Thousand Oaks: CA Sage Publications.

Newton, N. (2010). The Use of Semi-Structured Interview in Qualitative Research: Strengths and Weaknesses, (1-11).

Noori, A., Shafie, N, H., Mashwani, H, U. \& Tareen, H. (2017). Afghan EFL Lecturers' Assessment Practices in the Classroom. Imperial Journal of Interdisciplinary Research .-3, -10, .

O’Doherty, D., Dromey, M., Lougheed, J., Hannigan, A., Last, J., \& Mcgrath, D. (2018). Barriers and Solutions to Online Learning in Medical Education An Integrative Review. BMC Medical Education, 18(1). https://doi:10.1186/s12909-018-1240-0.

Putri, N. S. (2019). Kahoot Application in English Language Teaching (ELT) Context: An Alternative Learning Strategy. Elsya : Journal of English Language Studies, 1(1), 11-15. https://doi.org/10.31849/elsya.v1i1.2488

Putri, S. E., Hamuddin, B., Nursafira, M. S., \& Derin, T. (2020). Discourse Analysis in E-Learning-Based Course Using Moodle Platform: An Experimental Design . REiLA : Journal of Research and Innovation in Language, 2(1), 19-26. https://doi.org/10.31849/reila.v2i1.3960

Rahim, M. N. (2019). Blended Learning Application in Teaching \& Learning English as a Second Language: A Conceptual Paper. $2^{\text {nd }}$ Language and Communication Postgraduate International Seminar (LCPIS) Proceedings, ISBN 978-9672171-73-7, 36-39.

Rahim, M. N. (2019). The Use of Blended Learning Approach in EFL Education. International Journal of Engineering and Advanced Technology, $8(5 \mathrm{C})$,

$1165-1168$ https://doi.org/10.35940/ijeat.e1163.0585c19.
Rahim, M. N. (2021). The Relationship Between the Time Spent on Facebook and GPA Scores of PostGraduates. International Journal of Multidisciplinary: Applied Business and Education Research, 2(1), 94-102. Retrieved from http://ijmaberjournal.org/index.php/ijmaber/article/ view/74.

Rahim, M. N., and Sandaran, S. C. (2020). EFL Teachers' Perceptions of the Barriers and Opportunities for Implementing eLearning at Afghanistan Universities. Universal Journal of Educational Research, 8(11C), 97-104. https://doi.org/10.13189/ujer.2020.082311.

Rahim, M. N., and Sandaran, S. C. (2021). The Implementation of E-learning Approach in EFL Education: An Organizational Perspective. Universe International Journal of Interdisciplinary Research, 1(9), 156-168. DOI: http://www.doi-ds.org/doilink/03.202198353846/UIJIR.

Rahim, M. N., Hui, Y. K., Johari, M. W., Md Noor, N., and Abu Bakar, Z. (2019). Mobile Learning Apps for Language Listening Skill. Proceeding of New Academia Learning Innovation (NALI 2019) Exhibition \& Competition, eISBN 978-967-217194-2, 147-150.

Rajaee, Harandi, S. (2015). Effects of E-Learning on Students' Motivation. 3rd International Conference on Leadership, Technology and Innovation Management. Procedia - Social and Behavioral Sciences $181,423-430$.

Shahnaz, Q., George, P., Son, V., Shabnam, H., Habib, S., Schroeder, J., \& Karim, Q. (2014). Effectiveness of Parent Education Through Mobile Technology in Afghanistan. Creative Education, 5, 1921-1928. http://dx.doi.org/10.4236/ce.2014.522215.

Shirkhani, Z., Vahedi, M., \& Arayesh, M. (2016). Identifying Barriers of E-learning Implementation By M.Sc. Students in Agricultural Faculty of Islamic Azad University, Ilam Branch. International Journal of Agricultural Management and Development, 6(3), 353-362.

Solangi, Z. A., Shahrani, F. A., \& Pandhiani, S. M. (2018). Factors Affecting Successful Implementation of Elearning: Study of Colleges and Institutes Sector RCJ Saudi Arabia. International Journal of Emerging Technologies in Learning , 13(06), 223. http://doi:10.3991/ijet. v13i06.8537.

Vygotsky, L. S. (1978). Mind in Society: The Development of Higher Psychological Processes. Cambridge, Mass.: Harvard University Press. 
Yacob, A., Kadir, A. Z., Zainudin, O., \& Zurairah, A. (2012). Student Awareness Towards E-learning in Education. Procedia - Social and Behavioral Sciences, 67, 93-101. http://doi: 10.1016/j.sbspro.2012.11.310. 